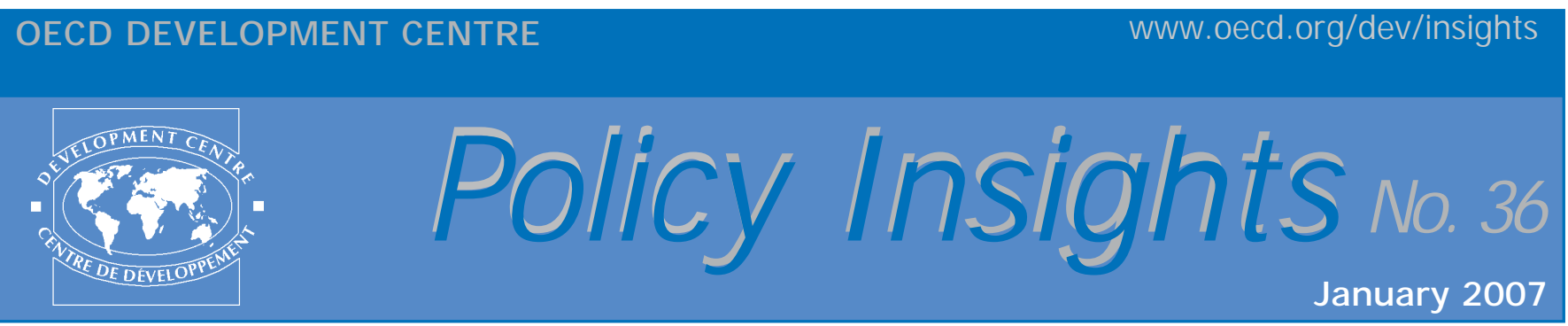

\title{
How to Lend to African Countries after a Decade of Debt Relief?
}

by Hélène Djoufelkit-Cottenet, Department of Research, French Development Agency

(Agence Française de Développement)

- The total amount of debt relief accorded to African countries in the framework of the Multilateral Debt Relief Initiative is expected to reach $\$ 43$ billion concerning 33 countries.

- The 15 African countries presently qualified for this Initiative will benefit from restored creditworthiness. Moreover, faced with considerable financing needs, African countries are prepared to take on new debts.

- Development partners can support this process of re-indebtedness provided that they employ extremely concessional, even counter-cyclical lending instruments, and also by strengthening co-ordination within the Debt Sustainability Framework.

\section{Debt in sub-Saharan Africa: restored but still fragile creditworthiness}

\section{Consolidating the benefits of the "Heavily I ndebted Poor Countries" I nitiative: the Multilateral Debt Relief I nitiative (MDRI )}

The Multilateral Debt Relief I nitiative (MDRI), which was launched at the G8 Summit held in Gleneagles in J une 2005, aims to go further than the enhanced Initiative for Heavily Indebted Poor Countries (HIPC I nitiative) which will have been in existence for ten years in 2006. This I nitiative aims to provide additional resources to 42 poor countries, including 33 African countries. It makes provision for the cancellation of 100 per cent of the multilateral debt stock contracted by eligible countries before 1 J anuary 2005 with the IMF and the African Development Fund (ADF, the concessional facility of the African Development Bank) and, before 1 January 2004, with the International Development Association (IDA, the concessional facility of the World Bank). The MDRI is important because multilateral debt represents more than 70 per cent of the remaining debt stock of African countries that have reached the completion point of the HIPC Initiative.
Breakdown by Donor of MDRI Effort

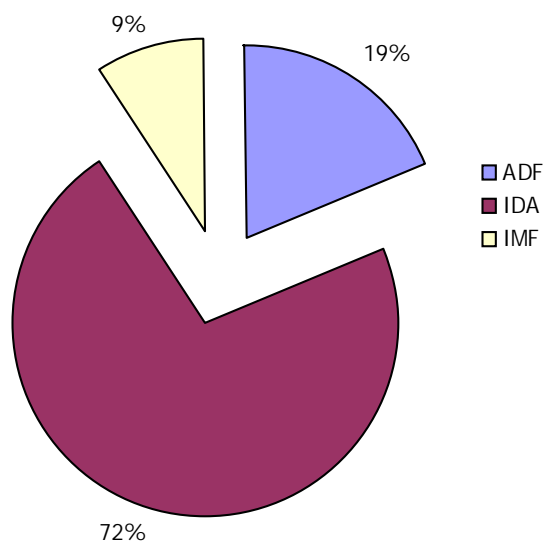

Sources: IMF, IDA, ADF. 
Eligible countries are poor countries that have reached, or are about to reach, the completion point of the HIPC I nitiative? In order to qualify, a country must then continue to satisfy the three conditions for reaching the completion point: i) demonstrate good macro-economic performance, ii) implement a poverty reduction strategy, and iii) adopt a public expenditure framework that complies with the crieria of good governance. All of the post-HIPC Initiative African countries qualified immediately, except for Mauritania which only qualified in J une 2006. (Prior to that date, the country failed to satisfy the first condition).

\section{The Multilateral Debt Relief I nitiative: an unprecedented effort}

The MDRI came into force on 1 J anuary 2006 for the IMF and the ADF, and on 1 J uly 2006 for the IDA. This I nitiative applies the criterion of additionality: each dollar cancelled must be refinanced by the international community. The cancellation is therefore not a substitute for future financing. The total cost of the I nitiative is estimated at approximately $\$ 50$ billion in nominal terms, borne mainly by the IDA which will accord debt cancellations of $\$ 37$ billion dollars (with $\$ 5$ billion for the IMF and $\$ 9$ billion for the ADF). The total amount of debt relief for African countries is expected to reach $\$ 43$ billion, $\$ 31.5$ billion of which concerns the 15 African post-HIPC I nitiative qualified countries ${ }^{3}$.

This is a substantial cancellation, since it represents at least 20 per cent of GDP for of the countries and as much as 97 per cent for a country such as Malawi. Cameroon is an exception: the total amount of cancellations represents only 8 per cent of its GDP. This is due to the fact that the HIPC I nitiative, along with its complementary bilateral arrangements - particularly France's C2D (Debt-reduction and Development Agreement) - had enabled the cancellation of most of Cameroon's debt, since two-thirds of it was bilateral.

After the cancellations, the Net Present Value (NPV) of debt represents on average 19 per cent of GDP and 65 per cent of exports of post-HIPC I nitiative countries. All of the African countries (except Niger and Rwanda) have, on average, indebtedness levels which are compatible with the sustainability thresholds defined within the Debt Sustainability Framework (DSF, cf. below) ${ }^{4}$. Thus all of the countries are rated by IDA as low- or medium-risk debtcrisis countries, and so become totally or partly eligible for IDA and ADF concessional loans.
Table 1. MDRI Cancellations and their I mpact on African Countries' Post-HI PC I nitiative Debt

\begin{tabular}{ccc}
$\begin{array}{c}\text { Cancellations as \% } \\
\text { of GDP* }\end{array}$ & $\begin{array}{c}\text { Debt service as } \% \\
\text { of exports** }\end{array}$ & $\begin{array}{c}\text { IDA risk } \\
\text { rating** }\end{array}$ \\
\hline 97.3 & 5.3 & Medium \\
49.3 & 3.7 & Low \\
45.0 & 11 & Low \\
39.0 & 3.8 & Low \\
37.3 & 4.4 & Low \\
36.4 & 9.5 & Low \\
35.7 & & Low \\
30.8 & 6.4 & High \\
30.7 & 1.6 & Low \\
29.8 & 6 & Low \\
28.7 & 4.4 & Low \\
25.2 & & High \\
24.9 & 2.4 & Low \\
24.8 & 5.1 & Low \\
20.2 & 1.5 & Low \\
8.1 & &
\end{tabular}

\section{How to lend to African Countries after a Decade of Debt Relief?}

\section{African countries' re-indebtedness: a calculated risk for donors}

The present context of still very fragile, but restored, creditworthiness makes the "loans or grants" dilemma especially acute, particularly for bilateral donors, who are now essentially dealing with grants to the Least-Developed Countries (LDCS) and Low-Income Countries (LICS). For these groups of countries, financing needs in order to reach the MDGs are in fact estimated at $\$ 135$ billion by the 2015 horizon (UN Millennium Project, 2005). However, all of those needs might not be entirely met by grants. In 2005, the latter represented "only" three-quarters of the aid allocated by Development Aid Committee (DAC) donors, that is, $\$ 81.4$ billion out of $\$ 106.5$ billion. Moreover, financing through loans is economically better-adapted than through grants when they do not threaten the creditworthiness of the country and when the interest rate on the loan is lower than the growth rate of the economy (and this is even more true in a context of limited public resources in the form of grants).

The decision to grant new loans to the LDCs and LICs can only be taken if bilateral donors have good reasons to believe that this indebtedness will not lead to new debt crises. Two new instruments presently being developed are designed to prevent a new spiral of loans and cancellations: the Debt Sustainability Framework (DSF), and innovative sovereign loans that are counter-cyclical in nature. 


\section{Setting limits on indebtedness}

A state's capacity to reimburse its debts depends both on its level of indebtedness and on its long-term macroeconomic performance. In Africa, the latter has not improved dramatically: growth rates are still largely dependent upon exogenous factors, and fail to ensure selfsustaining growth based on endogenous mechanisms of wealth creation. The only means of limiting overindebtedness seems therefore to reside in limiting the levels of indebtedness of these countries in the short- and medium-term.

The DSF developed jointly by the IMF and the World Bank aims therefore to set a ceiling to indebtedness above which the risk of non-reimbursement becomes very high (IMF/ World Bank, 2004). It is based on recognition of the fact that past over-indebtedness was due to over-optimism with respect to: i) the institutional capacity of states to conduct good policies and manage indebtedness; ii) the evolution of future economic performance. In the above context, the DSF aims to control the re-indebtedness process of postHIPC I nitiative countries by limiting its pace according to the economic situation and institutional capacity of the countries. Hence, exact debt ratios correspond to each level of economic and institutional performance, as measured by the CPIA ( "Country Policy and Institutional Assessment") indicator of the World Bank (World Bank, 2005).

The aspiration of DSF is that all donors stop lending when sustainability thresholds are crossed. At the heart of the DSF mechanism lie issues of co-ordination among donors and the assumption of responsibility for the sustainability framework by borrowing countries, and these issues are far from being solved. Co-ordination with "emerging" donors (i.e. not members of DAC) remains particularly problematic. Prudence is therefore called for when evaluating countries' indebtedness, even if the analysis of debt sustainability carried out annually by the IMF in the framework of Article IV is, in principle, a guarantee of transparency in public finance.

\section{Innovative financing instruments}

To the extent that economic shocks are one of the main causes of debt crises, counter-cyclical financial instruments, along with the DSF, would help to prevent them. During favourable periods, debt service disbursements (capital and interest payments) would continue as usual, or else be increased. During periods of economic shocks, capital payments would be reduced, rescheduled, or cancelled. There are pragmatic reasons for proposing this type of instrument, and they are based on lessons learned from past experience. One cannot however help wondering whether this approach does not risk creating additional "moral hazard" - by encouraging borrowing countries to adopt lax economic policies - thus hindering the development of a culture of credit and good debt management. This is why it is important to define triggering thresholds for these instruments relating to shocks that are both exogenous and unmanageable for the countries confronted by them.

\section{Notes}

1. The publication of Policy Insights No. 36 follows the organisation in Paris on 8 June 2006 of the joint ADF-OECD Development Centre experts' seminar entitled "African Economic Outlook 20052006: A Two-speed Continent?".

2. In order to respect the principle of uniformity of treatment among countries, the IMF also considers eligible all countries in which the per capita GDP is less than $\$ 380$, including those countries which did not benefit from the HIPC I nitiative. Their qualification depends on the same conditionality criteria as for post-HIPC Initiative countries. Two countries are concerned: Cambodia and Tajikistan.

3. Malawi and Sierra Leone reached the completion point respectively in August and December 2006; MDRI relief would enable them to benefit from an additional debt cancellation of respectively $\$ 1.4$ billion and $\$ 556$ million.

4. These thresholds vary according to countries' debt management capacity, which is calculated according to their CPIA ("Country Policy and Institutional Assessment") score (a World Bank indicator). For countries assessed as having "medium" capacity $(3.25<$ CPIA $<3.75)$, the thresholds are 150 per cent, 40 per cent and 20 per cent respectively for the ratios of external public debt stock to exports, external public debt stock to GDP, and external public debt service to exports.

\section{Sources:}

After Gleneagles: What role for loans in ODA? by Daniel Cohen, Pierre J acquet and Helmut Reisen, OECD Development Centre Policy Brief No. 31, November 2006, Paris.

UN Millennium Project (2005), Investing in Development. http:// www.unmillenniumproject.org/documents/MainReportChapter17lowres.pdf

IMF/World Bank (2004) Debt Sustainability in Low-Income Countries: Further Considerations on an Operational Framework and Policy Implications. http://www.imf.org/external/np/pdr/sustain/2004/ 091004.htm

World Bank (2005) Country Policy and Institutional Assessments 2005 Assessment Questionnaire

http://siteresources.worldbank.org//DA/Resources/ CPIA2005Questionnaire.pdf

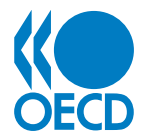

Readers are encouraged to quote or reproduce material from OECD Development Centre Policy I nsights for their own publications. In return, the Development Centre requests due acknowledgement and a copy of the publication. Full text of Policy Insights and more information on the Centre and its work are available on its web site: www.oecd.org/dev

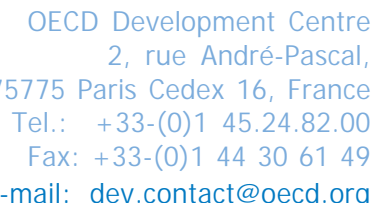

